\title{
Cacalia hastata L.: anti-influenza activity and phytochemical characteristics of extracts
}

\author{
Irina Lobanova ${ }^{1 *}$, Ekaterina Filippova ${ }^{2}$, Olga Kotsupiy $^{1}$, Maria Protsenko ${ }^{2}$, Tatiana \\ Kharina $^{3}$, Natalia Mazurkova ${ }^{2}$ \\ ${ }^{1}$ Central Siberian Botanical Garden SB RAS, 630090 Novosibirsk, Russia \\ ${ }^{2}$ State Scientific Center of Virology and Biotechnology VECTOR, 630559 Koltsovo, Russia \\ ${ }^{3}$ Siberian Botanical Garden at Tomsk State University, 634050 Tomsk, Russia
}

\begin{abstract}
This is the first study to assess antiviral activity against human influenza virus $\mathrm{A} / \mathrm{Aichi} / 2 / 68$ and bird influenza virus A/chicken/Kurgan/05/2005 and phytochemical characteristics of an ethanol extract of Cacalia hastata L. from wild populations growing in the vicinity of Tomsk, Russia (mixed forest). A $\log _{10}$ neutralization index-an indicator of inhibition of virus replication by the extract from $C$. hastata leaves-was $\leq 2 \mathrm{lg}$ for each influenza virus. The extract reduced the infectivity of the human influenza virus by 1.5 -fold and that of the avian influenza virus by 1.7 -fold. The phytochemical characterization of $C$. hastata (its various organs) showed that the largest amount of the tested biologically active substances is present in leaves and rhizomes.
\end{abstract}

\section{Introduction}

Cacalia hastata L. (family Compositae), also known as Parasenecio hastatus (L.) H. Koyama, is widely used in folk medicine (Russian, Mongolian, and Tibetan) as an effective wound-healing remedy with bactericidal and anti-inflammatory properties. C. hastata in various forms is used against respiratory infections, asthenia, and rheumatoid arthritis and as a laxative, choleretic, antipyretic, hemostatic, antitumor, and protistocidal agent, among other applications [1-7].

The wide variety of useful properties of $C$. hastata is explained by the presence of various biologically active substances (BASs), which determine its pharmacotherapeutic activity. The interest of conventional medicine in $C$. hastata is extremely strong: this species has been studied in Russia as a promising herb from folk medicine since the middle of the last century $[8,9]$. The plant is not only capable of a laxative effect but also has wound healing, anti-inflammatory, and antispasmodic properties [10-12]. To date, chemical composition of this plant has been investigated quite thoroughly; BASs belonging to various classes of chemical compounds are present in $C$. hastata plant material: various families of phenolic compounds (e.g., flavonoids, coumarins, phenol carboxylic acids, and their derivatives), terpenoids (e.g., tri- and tetraterpenoids and mono- and sesquiterpenoids),

\footnotetext{
* Corresponding author: irevlob@ngs.ru
} 
mono-, di-, and polysaccharides, organic acids, alkaloids (хастацин), and some others [1315].

At the Institute of General and Experimental Biology (SB RAS, Ulan-Ude), a 5\% liniment of $C$. hastata has been prepared from a dry-leaf extract, and its pharmacotherapeutic efficacy as an anti-inflammatory agent has been confirmed [16]. A pronounced cardioprotective activity of $C$. hastata leaves has also been documented [17]. Additionally, in the experiments of researchers from this country and from abroad, it has been found that various types of extracts from $C$. hastata leaves have antioxidant, antistress, hypoglycemic, and other properties $[11,17,18]$. In a review article by $\Pi . \Gamma$. Попов [19], there is an indication for the use of $C$. hastata leaves in various forms against respiratory diseases, and the list includes diseases caused by the influenza virus of various subtypes. Nonetheless, we are not aware of reports on anti-influenza properties of $C$. hastata from Siberia against human or avian influenza viruses. Therefore, the aim of this work was to experimentally evaluate $C$. hastata phytochemical characteristics and a possible antiviral activity of ethanol extracts of $C$. hastata against the influenza A virus.

\section{Material and methods}

C. hastata is a perennial rhizome plant $40-150 \mathrm{~cm}$ in height. In Russia, it has a wide geographic range: from the Arctic and the European part of the country to Western and Eastern Siberia and the Far East. Outside of Russia, it occurs in Eastern Europe and North Asia (Korea, northeastern China, and northern Japan). It grows in forests, river valleys, within bushes, and in forest riverside meadows [6, 7].

Samples of aboveground and underground parts of $C$. hastata growing in a mixed forest in the vicinity of Tomsk (Russia) served as the material for this study. The plant material was collected in the flowering phase, divided into organs, dried under natural conditions in the shade, and stored in paper bags.

Dry extracts were prepared by ethanol extraction and fourfold remaceration at $60{ }^{\circ} \mathrm{C}$. The ratio of the raw material to the extractant (70\% ethanol) was 1:50, and total extraction time was $8 \mathrm{~h}[20]$.

When determining the antiviral properties and testing the cytotoxicity of the C. hastata ethanol extracts, we utilized immortalized cells (cocker spaniel kidney cells; MDCK) obtained from the Cell Culture Collection at the SSC VB VECTOR (Koltsovo, Novosibirsk Oblast, Russia). The cells were grown for 2 days in 96-well plates in the RPMI 1640 medium (Biolot, Russia) supplemented with $10 \%$ of inactivated fetal calf serum (HyClone, USA) and antibiotics (100 IU/ml penicillin and $100 \mu \mathrm{g} / \mathrm{ml}$ streptomycin, Russia) at $37 \square$, $5 \% \mathrm{CO}_{2}$, and $100 \%$ humidity. For the cytotoxicity assay, a tested sample was diluted severalfold with the medium, and a monolayer of MDCK cells was covered with this solution. After 2 days of incubation at $37 \square, 5 \% \mathrm{CO}_{2}$, and $100 \%$ humidity, cytotoxic effects were evaluated under an inverted microscope, and maximum tolerable concentration (MTC) of the extract was calculated for these cultured cells [21].

In the assay of antiviral activity, we used avian influenza virus A/chicken/Kurgan/05/2005 (H5N1) and the human influenza virus A/Aichi/2/68 (H3N2) adapted to laboratory mice; the viruses were obtained from the State Collection of Viral and Rickettsial Disease Agents at the SSC VB VECTOR. The influenza virus particles were produced and titrated by means of the immortalized cells (the MDCK cell line).

The antiviral activity of each tested sample was assessed according to a change in influenza virus infectivity (titer) toward the monolayer of MDCK cells using MTC. For this purpose, $50 \mu \mathrm{l}$ of an extract diluted with the RPMI 1640 medium supplemented with 2 $\mu \mathrm{g} / \mathrm{ml}$ TPCK trypsin (Sigma, USA) was added into wells of a 96-well plate $1 \mathrm{~h}$ before the infection of the monolayer. The cells were infected with 10 -fold serial dilutions of the virus 
(eight dilutions total including the undiluted sample) prepared with the RPMI 1640 medium supplemented with $2 \mu \mathrm{g} / \mathrm{ml}$ trypsin. Uninfected cells cultured in the RPMI 1640 medium and cells infected with influenza virus A/Aichi/2/68 or A/chicken/Kurgan/05/2005 without a plant extract served as controls. The cell monolayers were incubated for 2 days in a thermostat at $37 \square, 5 \% \mathrm{CO}_{2}$, and $100 \%$ humidity, and the virus in the culture medium was detected by the hemagglutination reaction. Influenza virus titers in the culture supernatant were calculated and compared by the Spearman-Kärber method, were expressed as a decimal logarithm of a $50 \%$ tissue culture infectious dose per milliliter $\left(\lg \mathrm{TCID}_{50} / \mathrm{ml}\right)$, and are presented as mean \pm standard deviation (SD) with a $95 \%$ confidence interval. Differences were considered significant at $\mathrm{p} \leq 0.05$ [22]. Based on the titers of the influenza virus, a $\log _{10}$ neutralization index (NI) was calculated as follows: $\mathrm{NI}=$ virus titer in control minus virus titer in the experiment (lg) [23].

Concentrations of the analyzed classes of BASs in $C$. hastata were determined on spectrophotometers SF-56 (Russia) and Agilent 8453 (USA).

Flavonols were quantified according to the method of B.В. Беликов and М.С. Шрайбер (1970), where a complexation reaction of flavonols with aluminum chloride is carried out (with optical density measurement at $\lambda=415 \mathrm{~nm}$ ). The concentration of flavonols was determined with the help of a calibration curve constructed by means of rutin from Sigma-Aldrich (USA) as a standard [24].

The quantitation of catechins was based on their ability to produce raspberry-colored staining when mixed with a solution of vanillin in concentrated hydrochloric acid $(\lambda=502 \mathrm{~nm})$. The concentration of catechins was determined via a conversion coefficient for (+/-)-catechin from Sigma (USA) [25].

Tannins-hydrolyzable tanning substances-were quantified by a technique based on the formation of a colored complex when tannins are mixed with a $2 \%$ aqueous solution of ammonium molybdate. The intensity of the resultant coloring was measured at $\lambda=420 \mathrm{~nm}$. The calculation of tannin concentration was performed using a government standard sample of tannin [26].

Coumarins were detected as follows: $0.1 \mathrm{~g}$ of the raw material was boiled for $2 \mathrm{~h}$ with $2.5 \mathrm{ml}$ of $1 \mathrm{~N}$ sodium hydroxide solution in $15 \mathrm{ml}$ test tubes in a water bath. Under these conditions, coumarin transformed into ortho-coumaric acid. Next, the volume of the solution in the tubes was brought to $15 \mathrm{ml}$ with water, and the solution was shaken and then incubated under ambient conditions for $\mathrm{X} \mathrm{h}$. An aliquot of the reaction mixture was placed into a colorless porcelain cup and examined under ultraviolet light. Coumarin-free extracts gave fluorescence of a faint brownish-red color, those containing a low coumarin level a red-green color, whereas coumarin-rich extracts yielded brilliant green fluorescence. For visual assessment of the concentration of coumarins, we employed the following notation: trace levels of coumarins: + , low coumarin concentration: ++ ; moderate coumarin concentration: +++ , and high coumarin concentration: $++++[27]$.

Carotenoids were quantitated via optical density of an acetone-ethanol extract at the wavelengths corresponding to absorption maxima of the following pigments: chlorophylls $a$ $(\lambda=662 \mathrm{~nm})$, chlorophylls $b(\lambda=644 \mathrm{~nm})$, and carotenoids $(\lambda=440.5 \mathrm{~nm})$; the carotenoid concentration was computed using the Wetstein and Holm equations [27].

When determining the level of saponins - by the gravimetric method-we evaporated the ethanol extract until the smell of alcohol disappeared, after which a sevenfold volume of acetone was added. After $18 \mathrm{~h}$, the formed precipitate was filtered off, dried, and weighed, and the amount of "crude saponin" was calculated [28].

Pectin substances (pectins and protopectins) were quantified by a carbazole-free method based on a specific yellow-orange color of uronic acids when mixed with thymol in a sulfuric acid solution; optical density of the colored solutions was measured at $\lambda=480 \mathrm{~nm}$. 
The level of pectin substances was determined from a calibration curve built by means of galacturonic acid [29].

\section{Results and discussion}

The results of this experimental study are given in Tables 1 and 2 .

Table 1 presents data on the anti-influenza activity of the ethanol extracts from $C$. hastata leaves. For the first time, an inhibitory activity against human influenza virus A/Aichi/2/68 (H3N2) and bird influenza virus A/chicken/Kurgan/05/2005 (H5N1) was found in extracts from $C$. hastata leaves, according to the NIs.

Table 1 Antiviral activity of ethanol extracts of $C$. hastata leaves against influenza viruses $\mathrm{A} / \mathrm{Aichi} / 2 / 68$ and $\mathrm{A} /$ chicken/Kurgan/05/2005 and their toxicity

\begin{tabular}{|c|c|c|c|c|c|}
\hline \multirow{2}{*}{ Type of samples } & \multirow{2}{*}{$\begin{array}{c}\text { MTC, } \\
\mathrm{mg} / \mathrm{ml}\end{array}$} & \multicolumn{4}{|c|}{$\begin{array}{c}\text { Virus titer, lg TCID } \\
\text { (mean } \pm \text { SD/95\% CI) }\end{array}$} \\
\cline { 3 - 6 } & $\begin{array}{c}\mathrm{A} / \text { Aichi/2/68 } \\
(\mathrm{H} 3 \mathrm{~N} 2)\end{array}$ & $\mathrm{NI}, \mathrm{lg}$ & $\begin{array}{c}\text { A/chicken/Kurgan/05/2005 } \\
(\mathrm{H} 5 \mathrm{~N} 1)\end{array}$ & NI, lg \\
\hline $\begin{array}{c}\text { Extracts of } C . \\
\text { hastata leaves }+ \\
\text { virus }\end{array}$ & 0.5 & $2.50 \pm 0.00^{*}$ & 1.33 & $2.50 \pm 0.00^{*}$ & 1.67 \\
\hline $\begin{array}{c}\text { Control virus } \\
\text { samples } \\
\text { (without extract) }\end{array}$ & - & $\begin{array}{c}3.83 \pm 0.33 \\
( \pm 0.65)\end{array}$ & - & $\begin{array}{r}4.17 \pm 0.33 \\
( \pm 0.65)\end{array}$ & - \\
\hline
\end{tabular}

Note: MTC is maximum tolerable concentration; NI is the $\log _{10}$ neutralization index; SD: standard deviation, CI: confidence interval; *a significant difference from the control virus (without extract) according to the Spearman-Kärber method, with differences being significant at $\mathrm{p} \leq 0.05$.

The NI is the most important indicator of an antiviral effect of potential antiviral drugs. In accordance with the Guidelines for the experimental (preclinical) study of new pharmacological substances, those that decrease the infectivity of a virus in cell culture by at least $2.0 \mathrm{lg}$ are considered promising for subsequent testing in vivo [23]. The NIs of the ethanol extracts from $C$. hastata leaves were found to be less than $2.0 \mathrm{lg}$; however, there was significant suppression of influenza virus replication in comparison with the control. In the cytotoxicity assay, it was demonstrated that the ethanol extracts from $C$. hastata leaves have low toxicity toward cultured MDCK cells $(\mathrm{MTC}=0.5 \mathrm{mg} / \mathrm{ml})$ and reduce $\mathrm{H} 3 \mathrm{~N} 2$ influenza virus infectivity by 1.5 -fold and $\mathrm{H} 5 \mathrm{~N} 1$ influenza virus infectivity by 1.7 -fold.

Phytochemical characteristics of $C$. hastata (its different organs) are presented in Table 2. Concentrations of some families of phenolic compounds (flavonols, catechins, tannins, and coumarins), terpenoids (saponins and carotenoids), and polysaccharides (pectin substances) were determined, as were their distributions among the plant organs. The leaves and rhizomes of $C$. hastata turned out to be the richest in terms of BAS content. The leaves contain the highest levels of virtually all the assayed families of BASs (flavonols, catechins, tannins, saponins, carotenoids, and protopectins) but are devoid of coumarins and contain only negligible amounts of pectins. The rhizomes were found to contain the highest concentrations of pectins and coumarins (by visual assessment) and negligible levels of flavonols, catechins, tannins, saponins, and carotenoids.

It is noteworthy that the insoluble form of pectins-protopectins-is present in all the tested organs of $C$. hastata, almost at the same concentration: $3.27-3.91 \%$ of air-dried weight. Furthermore, their highest level was found in stalks, and the lowest in inflorescences. Overall, the leaves of $C$. hastata can be considered a source of flavonols, saponins, carotenoids, and protopectin, whereas its rhizomes are a source of coumarins and pectin substances. The results of this phytochemical characterization are consistent with the 
data from folk medicine and confirm the findings from the field of conventional medicine, namely, that it is $C$. hastata leaves that are usually used as medicinal raw materials, whereas rhizomes are employed less often, of course, depending on the purpose of the raw materials' use. We should mention that continued research on the plants that have long been applied in folk medicine is one of the relevant and important fields of pharmacology and provides the basis for comprehensive and in-depth studies on the profile of biological effects of such plants as well as for the introduction of related drugs into clinical practice.

Table 2 BASs of $C$. hastata

\begin{tabular}{|c|c|c|c|c|c|c|c|c|}
\hline \multirow{4}{*}{$\begin{array}{c}\text { Organs } \\
\text { of } C . \text { hastata }\end{array}$} & \multicolumn{8}{|c|}{ BASs, (\% of air-dried weight) } \\
\hline & \multicolumn{4}{|c|}{ Phenolic compounds } & \multicolumn{2}{|c|}{ Terpenoids } & \multicolumn{2}{|c|}{$\begin{array}{c}\text { Polysaccharides } \\
\text { (pectin substances) }\end{array}$} \\
\hline & \multicolumn{2}{|c|}{ flavonoids } & \multirow{2}{*}{$\begin{array}{c}\operatorname{tani-} \\
\text { nis }\end{array}$} & \multirow{2}{*}{$\begin{array}{c}\text { coumar } \\
\text { ins } * *\end{array}$} & \multirow[b]{2}{*}{ tri- } & \multirow[b]{2}{*}{ tetra-* } & \multirow[b]{2}{*}{ pectins } & \multirow[b]{2}{*}{$\begin{array}{l}\text { protope } \\
\text {-ctins }\end{array}$} \\
\hline & flavonols & $\begin{array}{l}\text { cate- } \\
\text { chins* }\end{array}$ & & & & & & \\
\hline leaves & $\begin{array}{c}2.32 \pm \\
0.08\end{array}$ & $\begin{array}{c}0.0013 \\
\pm \\
0.0000\end{array}$ & $\begin{array}{c}0.25 \\
\pm \\
0.00\end{array}$ & absent & $\begin{array}{c}14.75 \\
\pm \\
0.33\end{array}$ & $\begin{array}{c}0.69 \pm \\
0.00\end{array}$ & $\begin{array}{c}0.72 \pm \\
0.01\end{array}$ & $\begin{array}{c}3.62 \pm \\
0.08\end{array}$ \\
\hline stalks & $\begin{array}{c}0.21 \pm \\
0.01\end{array}$ & $\begin{array}{c}0.0004 \\
\pm \\
0.0000\end{array}$ & $\begin{array}{c}0.02 \\
\pm \\
0.00\end{array}$ & $\begin{array}{c}\text { modera } \\
\text {-te } \\
\text { level }\end{array}$ & $\begin{array}{l}9.18 \pm \\
0.25\end{array}$ & $\begin{array}{c}0.024 \pm \\
0.000\end{array}$ & $\begin{array}{c}2.19 \pm \\
0.07\end{array}$ & $\begin{array}{c}3.91 \pm \\
0.09\end{array}$ \\
\hline inflorescences & $\begin{array}{l}1.08 \pm \\
0.03\end{array}$ & $\begin{array}{c}0.0007 \\
\pm \\
0.0000\end{array}$ & $\begin{array}{c}0.09 \\
\pm \\
0.00\end{array}$ & $\begin{array}{l}\text { low } \\
\text { level }\end{array}$ & $\begin{array}{c}8.19 \pm \\
0.21\end{array}$ & $\begin{array}{c}0.113 \pm \\
0.000\end{array}$ & $\begin{array}{l}1.56 \pm \\
0.05\end{array}$ & $\begin{array}{l}3.27 \pm \\
0.07\end{array}$ \\
\hline rhizomes & $\begin{array}{c}0.15 \pm \\
0.00\end{array}$ & $\begin{array}{c}0.0007 \\
\pm \\
0.0000\end{array}$ & $\begin{array}{c}0.04 \\
\pm \\
0.00\end{array}$ & $\begin{array}{l}\text { high } \\
\text { level }\end{array}$ & $\begin{array}{l}6.60 \pm \\
0.15\end{array}$ & $\begin{array}{c}0.021 \pm \\
0.000\end{array}$ & $\begin{array}{c}2.77 \pm \\
0.09\end{array}$ & $\begin{array}{c}3.66 \pm \\
0.08\end{array}$ \\
\hline
\end{tabular}

Note: *Concentrations of catechins and carotenoids are given in $\mathrm{mg} / \mathrm{g} ; * *$ The level of coumarins was evaluated visually, according to the intensity and color of fluorescence.

\section{Conclusion}

For the first time, in an experimental study, we showed that an ethanol extract from $C$. hastata leaves has antiviral activity against human influenza virus A/Aichi/2/68 and bird influenza virus A/chicken/Kurgan/05/2005. The infectivity of the influenza H3N2 and H5N1 viruses was reduced by the extract by 1.5- and 1.7-fold, respectively.

Phytochemical characterization of the C. hastata plant material (various organs) revealed that in the flowering phase, leaves and rhizomes are the richest source of BASs. $C$. hastata leaves contain the highest levels of flavonoids (flavonols and catechins), tannins, and terpenoids (saponins and carotenoids), whereas rhizomes feature the highest concentrations of pectins and coumarins (according to visual assessment). Stalks and inflorescences can also serve as a source of pectin substances. Therefore, C. hastata can be employed as medicinal raw material depending on the purpose.

This work was supported by a project (No. AAAA-A21-121011290025-2) within a state assignment for the Central Siberian Botanical Garden (SB RAS) as part of a state contract.

The results of this study were obtained as part of a state assignment for the SSC VB VECTOR.

\section{References}

1. T. A. Aseeva, K. F. Blinova, G. Yakovlev Medicinal Plants of Tibetan Medicine, (Novosibirsk, 1989) 
2. G. V. Krylov, N. F. Kozakova, A. A. Lager, Plants of health (Novosibirsk, 1989)

3. K. F. Blinova, V. B. Kuvaev, Pharmacognosy issues 19 (1965)

4. C. Haidav, Healing Remedies of Folk Medicine of Mongolia 12 (1969)

5. I. I. Grom, Pharmacognosy issues 3 (1965)

6. Plant resources of the USSR: Floral plants, their chemical composition, uses; Family 7. Asteraceae (Compositae) (SPb., Nauka, 1993)

7. Plant resources of Russia: Wild flowering plants, their component composition and biological activity. Family Asteraceae. (Compositae) (SPb-M., KMK, 2012)

8. E. K. Denisova, Pharmacognostic study of Cacalia hastata as a folk wound healing agent (L., 1950)

9. F. I. Deryabina, Pharmacognostic study of medicinal plants of folk medicine of the Komi-Permyak National District (L., 1965)

10. L. V. Mazur, The influence of ecological and phytocenotic factors on the content and distribution of biologically active substances in Cacalia hastata L.: Southwestern Transbaikalia (Ulan-Ude, 2002)

11. M. I. Balhaev, Bulletin of the All-Russian Scientific Center SB RAMS 13 (2005)

12. A. V. Borgolov, Pharmacotherapeutic efficacy of liniment of Cacalia hastata in experimental injuries and ectopia of the cervix (experimental clinical study) (UlanUde, 2006).

13. G. J. Papariella, N. A. Janish, Chem. Lett. 38 (1966)

14. K. Naya, J. Miyshi, H. Mori, K. Takai, M. Nakanishi, Chem.Lett. 1 (1976)

15. D. N. Olennikov, Phytochemical study of leaves of Cacalia Hastata L. (Ulan-Ude, 2003)

16. Method of obtaining remedy possessing anti-inflammatory activity: Patent № 2206333 Russian Federation, MKI A61K 35/78 /M. I. Balhaev, E.G. Grigoriev, A.S. Kogan, P.B. Lubsandarzhieva, S.M. Nikolaev, D.N. Olennikov, D.V. Sandanov, I.O. Ubasheev; applicant and patent holder, Institute of General and Experimental Biology, Siberian Branch of RAS (Ulan-Ude) - No 200219969/14; stated. 22.07.2002; Published 20.06.2003 (2002)

17. Method of obtaining remedies possessing cardioprotective activity: patent: № 2 240814 C 1 Russian Federation IPK A61P9/10 / D.N. Olennikov, S.M. Nikolaev, A.V. Tsyrenzhapov, G.G. Nikolaeva, L.M. Tankhaeva, L.B. Buraeva; applicant and patentee Institute of General and Experimental Biology SB RAS (Ulan-Ude); Decl. 05.15. 2003; Published 27.11.2004 (2003)

18. D. Jambaninj, S. Sulaiman, S. Gillani, T. S. Davaasuren, G. Erdenetsetseg, D. Dungerdorj, J Adv. Pharm. Technol. Res. 3 (1) (2012)

19. P. L. Popov, J. of Stress Physiology \& Biochemistry 4 (2008)

20. H. E. Kostina, Zh. B. Ibragimova, M. A. Protsenko, E. V. Makarevich, M. A. Skarnovich, E. I. Filippova, I. A. Gorbunova, V. A. Vlasenko, G. P. Troshkova, N. A. Mazurkova, L. N. Shishkina, Contemporary Issues of Science and Education 3 (2013)

21. N. A. Mazurkova, E. I. Filippova, E. V. Makarevich, I. E. Lobanova, G. I. Vysochina, Biological, medical and pharmaceutical chemistry issues 4 (2014)

22. L. Zaks, Statistical estimation (M.: Statistics, 1976).

23. Guidelines for experimental (preclinical) study of new pharmacological substances (M., Medicine, 2005)

24. B. V. Belikov, M. S. Schreiber, Pharmacy 1 (1970). 
25. T. A. Kukushkina, A. A. Zykov, L. A. Obukhova, Actual problems of creating new drugs of natural origin, Proceedings of the UP International Congress of Phytopharm. 03 - 05 July 2003, SPb. (2003)

26. L. M. Fedoseeva, Chemistry of Plant Raw Materials 2 (2005)

27. Methods of biochemical analysis of plants (L., 1987)

28. A. V. Kiseleva, T. A. Volkhonskaya, V. E. Kiselev. Biologically active substances of medicinal plants of Southern Siberia (Novosibirsk, 1991)

29. V. I. Kriventsov, Proceedings of the Nikitsky Botanical Garden 109 (1989) 